\title{
Analisis Kemampuan Keuangan Daerah Pada Daerah Tertinggal di Provinsi Sulawesi Tengah
}

\author{
Rycha Kuwara Sari ${ }^{1 *}$, Choiroel Woestho ${ }^{1}$, Milda Handayani ${ }^{1}$ \\ ${ }^{1}$ Fakultas Ekonomi dan Bisnis; Universitas Bhayangkara Jakarta Raya; Jl. Harsono RM \\ Dalam No.46, RT.7/RW.4, Ragunan, Kec. Ps. Minggu, Kota Jakarta Selatan, (021) 7231948; e- \\ mail: rycha@dsn.ubharajaya.ac.id, choiroel@dsn.ubharajaya.ac.id, \\ * Korespondensi: e-mail: rycha@dsn.ubharajaya.ac.id \\ Submitted: 13/10/2020; Revised: 15/12/2020; Accepted: 4/01/2021; Published: 15/01/2021
}

\begin{abstract}
The regional capacity in managing the budget as reflected in the Regional Revenue and Expenditure Budget (APBD) means describing how the region's ability to finance any development activity by applying the principle of equity and justice by using regional potential. The research methodology used is descriptive research method. This method was chosen by the researcher in order to obtain an overview of various actual information in detail which is described in the aspect of regional financial capacity as measured by PAD share, PAD growth and PAD elasticity which are then combined into the regional financial capacity index method. The data selected is panel data in the form of the Regional Revenue and Expenditure Budget from 9 Districts / Cities that are categorized as disadvantaged areas during the 2015-2019 period which were obtained from the Directorate General of Fiscal Balance, Ministry of Finance. The results obtained are 6 districts that are classified as high regional financial capacity, 2 districts are classified as medium and 1 district are classified as low.
\end{abstract}

Keywords: Disadvantaged Regions, PAD Growth, PAD Elasticity, Regional Financial Capability Index, Share of PAD,

\begin{abstract}
Abstrak
Kemampuan daerah dalam mengelola anggaran yang tercermin dalam Anggaran Pendapatan dan Belanja Daerah (APBD) berarti menggambarkan bagaimana kemampuan daerah dalam membiayai setiap kegiatan pembangunan dengan menerapkan prinsip pemerataan dan berkeadilan dengan menggunakan potensi daerah. Metodologi penelitian yang digunakan adalah metode penelitian deskriptif. Metode ini dipilih oleh peneliti agar mendapatkan gambaran dari berbagai informasi aktual secara terperinci yang digambarkan pada aspek kemampuan keuangan daerah yang diukur melalui share PAD, growth PAD dan elasticity PAD yang kemudian dikombinasikan ke dalam metode indeks kemampuan keuangan daerah. Data yang dipilih merupakan data panel yang berupa Anggaran Pendapatan dan Belanja Daerah dari 9 Kabupaten/Kota yang masuk kategori daerah tertinggal selama rentang tahun 2015 - 2019 yang diperoleh dari Direktorat Jenderal Perimbangan Keuangan Kementerian Keuangan. Hasil yang diperoleh ada 6 Kabupaten yang masuk dalam klasifikasi kemampuan keuangan daerah tinggi, 2 Kabupaten masuk kedalam klasifikasi sedang dan 1 Kabupaten masuk dalam klasifikasi rendah.
\end{abstract}

Kata kunci: Daerah Tertinggal, Growth PAD, Elasticity PAD, Indeks Kemampuan Keuangan Daerah, Share PAD

\section{Pendahuluan}

Peluang daerah untuk melakukan pembangunan daerah sesuai dengan kebutuhan dan prioritas daerahnya mulai terbuka sejak ditetapkannya Undang - Undang Nomor 23 Tahun 2014 tentang Pemerintahan Daerah dan Undang - Undang Nomor 33 Tahun 2004 tentang 
Perimbangan Keuangan antara Pemerintah Pusat dan Pemerintah Daerah. Penetapan Undang - Undang ini diikuti adanya perubahan kewenangan dalam proses penyelenggaraan pembangunan yang selama ini dipegang oleh pemerintah pusat.

Perubahan kewenangan dari pemerintah pusat kepada pemerintah daerah mempunyai konsekusensi dimana pemerintah daerah wajib untuk menjalankan pembangunan daerahnya secara baik dengan memperhatikan pemerataan yang berkeadilan dengan menggunakan potensi daerah, termasuk mengikutsertakan masyarakat dalam proses pembangunan daerah.

Dalam melakukan pembangunan daerah, pemerintah daerah perlu melakukan perencanaan dan penganggaran daerah. Perencanaan dan penganggaran daerah merupakan cerminan dari pefektifitas pengelolaan keuangan daerah yang baik dalam menunjang keberhasilan desentralisasi fiskal. Efektifitas pengelolaan keuangan daerah dilihat dari penggunaan Anggaran Pendapatan dan Belanja Daerah (APBD).

APBD merupakan sumber pendanaan pasti bagi pemerintah daerah yang sudah diamanatkan dalam Undang - Undang Nomor 23 Tahun 2014 tentang Pemerintahan Daerah yang kemudian diturunkan ke dalam Peraturan Pemerintah Nomor 12 Tahun 2019 tentang Pengelolaan Keuangan Daerah dengan tetap menjaga tata pengelolaan keuangan daerah yang baik yaitu transparansi, akuntabilitas dan partisipatif. APBD merupakan rencana keuangan tahunan daerah yang sudah direncanakan dalam Rencana Pembangunan Jangka Menengah Daerah (RPJMD) dan kemudian ditetapkan dengan peraturan daerah. Dalam APBD, pos anggaran selain sumber - sumber pendanaan atau pendapatan daerah, juga terdapat belanja daerah dan pembiayaan.

APBD merupakan gambaran tentang kemampuan dari pemerintah daerah dalam melakukan aktivitas pembangunan daerah dimana di dalamnya terdapat sumber - sumber pendapatan daerah serta belanja dan pembiayaan daerah. Dalam menghitung efektifitas pengelolaan anggaran, salah satu teknik yang dilakukan yaitu analisis kemampuan keuangan daerah dengan menggunakan metode indeks untuk mengetahui pola peta kemampuan keuangan daerah dan pola hubungan kemampuan keuangan daerah.

Dalam melaksanakan otonomi daerah, ada empat elemen penting yang diserahkan pemerintah pusat kepada pemerintah daerah, diantaranya desentralisasi politik, derajat desentralisasi, desentralisasi administrasi dan desentralisasi ekonomi (Kamaroellah, 2017). Keempat elemen tersebut menjadi kewajiban bagi daerah dalam mengelola secara efisien dan efektif. Derajat desentralisasi merupakan komponen utama dalam penerapan otonomi daerah terutama untuk pembangunan daerah terutama dalam mengelola sumber daya yang dimiliki sebagai perwujudan kesejahtaraan dan kemajuan daerah.

Kemampuan daerah dalam mengelola anggaran yang tercermin dalam Anggaran Pendapatan dan Belanja Daerah (APBD) berarti menggambarkan bagaimana kemampuan daerah dalam membiayai setiap kegiatan pembangunan dengan menerapkan prinsip pemerataan dan berkeadilan dengan menggunakan potensi daerah. Penyusunan Angaran Pendapatan dan Belanja Daerah (APBD) harus mengacu kepada norma-norma serta prinsip 
anggaran, yaitu: (1) Transparansi dan Akuntabiltas Anggaran, (2) Disiplin Anggaran, (3) Keadilan Anggaran, (4) Efisiensi dan Efektivitas Anggaran dan (5) Format Anggaran.

Angaran Pendapatan dan Belanja Daerah (APBD) yang disusun berdasarkan pendekatan kinerja tersebut memuat hal-hal sebagai berikut: (1) Sasaran yang ditetapkan menurut fungsi belanja, (2) Standar pelayanan yang diharapkan dan perkiran biaya satuan komponen kegiatan yang bersangkutan, (3) Bagian pendapatan Angaran Pendapatan dan Belanja Daerah (APBD) yang membiayai belanja administrasi umum, belanja operasi dan pemeliharan, dan belanja modal atau pembangunan.

Ciri utama dari pelaksanaan otonomi daerah terletak pada kemampuan keuangan daerah dalam membiayai penyelenggaraan pemerintah dengan tingkat ketergantungan kepada pemerintah pusat yang harus mempunyai proporsi yang kecil sehingga diharapkan Pendapatan Asli Daerah (PAD) harus menjadi bagian terbesar dalam mobilisasi dana.

Penelitian ini berfokus kepada kajian kemampuan keuangan daerah pada daerah tertinggal yang ada di Provinsi Sulawesi Tengah. Berdasarkan Peraturan Presiden Nomor 131 Tahun 2015 tentang Penetapan Daerah Tertinggal Tahun 2015 - 2019, daerah tertinggal merupakan daerah yang wilayah serta masyarakatnya kurang berkembang dibandingkan dengan daerah lain dalam skala nasional. Dalam Peraturan tersebut juga dijelaskan, yang ditetapkan sebagai daerah tertinggal dilihat dari kriteria antara lain : perekonomian masyarakat, sumber daya manusia, sarana dan prasarana, kemampuan keuangan daerah, aksesibilitas dan karakteristik daerah.

Dengan menilai kemampuan keuangan daerah dalam mengelola APBD dapat diperoleh gambaran tentang kemampuan pemerintah daerah dalam melakukan aktivitas pembiayaan pelaksanaan tugas pembangunan, pemerataan, dan keadilan melalui pengembangan seluruh potensi yang dimiliki oleh masing-masing daerah (Susanto, 2014).

\section{Metode Penelitian}

Metodologi penelitian yang digunakan adalah metode penelitian deskriptif. Metode ini dipilih oleh peneliti agar mendapatkan gambaran dari berbagai informasi aktual secara terperinci yang digambarkan pada aspek kemampuan keuangan daerah yang diukur melalui share PAD, growth PAD dan elasticity PAD yang kemudian dikombinasikan ke dalam metode indeks kemampuan keuangan daerah yang pernah dilakukan oleh Kementerian Perencanaan Pembangunan Nasional atau Badan Perencanaaan Pembangunan Nasional.

Penggunaan metode ini dapat bermanfaat sebagai sarana untuk menggambarkan secara sistematis fakta maupun karakteristik dari daerah tertinggal di Provinsi Sulawesi Tengah, sehingga dapat dihasilkan rekomendasi kebijakan. Sementara, pendekatan penelitian dalam kajian ini menggunakan pendekatan kuantitatif. Data yang dipilih merupakan data panel yang berupa Anggaran Pendapatan dan Belanja Daerah dari 9 Kabupaten/Kota yang masuk kategori daerah tertinggal selama rentang tahun 2015 - 2019 yang diperoleh dari Direktorat Jenderal Perimbangan Keuangan Kementerian Keuangan. 
Untuk mengetahui indeks kemampuan keuangan daerah (IKKD), dilakukan langkah langkah sebagai berikut :

1. Perhitungan dan analisis Kinerja PAD melalui ukuran indeks share, indeks growth dan indeks elastisitas dapat diukur sebagai berikut :

$$
\begin{aligned}
& \text { Share PAD } \quad: \frac{\text { PADt }}{\text { Total Belanja }} \times 100 \% \\
& \text { Growth PAD } \quad: \frac{P A D t-P A D t-1}{P A D t-1} \times 100 \% \\
& \text { Elasticity } P A D \quad: \quad \frac{\text { Growth } P A D}{\text { Growth } P D P D} \\
& \overline{\text { Growth } P D R B} \quad \text { 3) } \\
& \text { Keterangan } \quad: \text { PADt } \quad \text { : Pendapatan Asli Daerah Tahun } t \\
& \text { : PADt-1 : Pendapatan Asli Daerah Tahun t-1 } \\
& \text { : PDRB : Pendapatan Domestik Regional Bruto }
\end{aligned}
$$

2. Menyususun Indeks untuk setiap komponen Indeks Kemampuan Keuangan. Indeks ini diperoleh dengan menggunakan persamaan berikut :

Indeks $X \quad \frac{\text { Nilai * hasil pengukuran-Nilai * kondisi minimum }}{\text { Nilai * kondisi maksimum -Nilai*kondisi minimum }}$

3. Dari persamaan (5), kemudian dihitung indeks kemampuan keuangan daerah yang diperoleh dari persamaan :

$$
\mathrm{IKK}: \frac{X s+X g+X e}{3}
$$

Keterangan

$$
\begin{aligned}
& \mathrm{Xs}=\text { Indeks Share PAD terhadap Belanja } \\
& \mathrm{Xg}=\text { Indeks Growth (Pertumbuhan PAD) } \\
& \mathrm{Xe}=\text { Indeks Elastisitas Pertumbuhan PAD terhadap Belanja Daerah }
\end{aligned}
$$

Jika sudah diperoleh nilai indeks kemampuan keuangan daerah, kemudian dapat dikelompokkan kedalam kriteria tingkat kemampuan keuangan daerah, sebagai berikut:

Tabel 1. Kriteria Tingkat Kemampuan Keuangan Daerah

\begin{tabular}{cc}
\hline Indeks Kemampuan Keuangan & Klasifikasi \\
\hline $0,00-0,33$ & Rendah \\
\hline $0,34-0,43$ & Sedang \\
\hline $0,44-1,00$ & Tinggi
\end{tabular}

Sumber: (Savitry et al., 2011) 
4. Menyusun peta kemampuan keuangan daerah berdasarkan IKK yang diperoleh dari persamaan (6). Berdasarkan range IKK tertinggi dan IKK terendah, kemudian disusun peta kemampuan keuangan yang dibagi dalam tiga kategori, yaitu tinggi, sedang dan rendah, yang berpedoman pada Halim (2001) dalam (Haryanto, 2018).

Tabel 2. Hubungan dan Tingkat Kemampuan Daerah

\begin{tabular}{ccc}
\hline Kemampuan Keuangan & Kemampuan (\%) & Pola Hubungan \\
\hline Rendah Sekali & $0-25$ & Instruktif \\
\hline Rendah & $26-50$ & Konsultatif \\
\hline Sedang & $51-75$ & Partisipatif \\
\hline Tinggi & $76-100$ & Delegatif
\end{tabular}

Sumber: (Haryanto, 2017)

\section{Hasil dan Pembahasan}

Otonomi daerah yang diterapkan di Indonesia, sebetulnya sudah banyak dilakukan di negara lain. Otonomi daerah yang dilakukan saat ini, memberikan kewenangan kepada pemerintah daerah dalam hal mengelola daerah mereka sendiri, termasuk dalam bidang ekonomi. Penerapan otonomi daerah, memungkinkan bagi pemerintah daerah dalam upaya mengembangkan kapasitas daerah yang dimiliki sesuai dengan keunggulan daerahnya.

Otonomi daerah merupakan bentuk nyata dari pelaksanaan teori kebijakan publik yang secara nyata khususnya jika dikaitkan dengan reformasi manajemen keuangan (Haryanto, 2016). Selama era transisi dalam penerapan otonomi daerah, beberapa permasalahan yang sering dihadapi diantaranya belum kuatnya perangkat hukum, kelembagaan, infrastruktur serta ketersediaan sumber daya manusia.

Daerah otonom merupakan wujud nyata dan dianutnya asas devolusi serta dekonsentrasi sebagai makna dari desentralisasi (Rinaldi, 2013). Otonomi daerah jika dipahami secara fungsional berarti memaksimalkan fungsi pemerintahan agar dapat dilakukan secara cepat, dekat dan tepat dengan kebutuhan masyarakat. Otonomi daerah juga tidak bergantung kepada siapapun atau dapat dimaknai sebagai kewenangan daerah dalam mengatur administrasi birokrasi, keuangan serta kebijakan publik dalam batasan yang telah ditetapkan dan disepakati bersama (Hruza, 2015).

Pengembangan otonomi pada level daerah kabupaten dan kota seharusnya diselenggarakan dengan lebih memerhatikan prinsip-prinsip demokrasi, peran serta masyarakat, pemerataan, dan keadilan serta memerhatikan potensi keanekaragaman daerah (Sasana, 2016).

Peraturan tentang otonomi daerah juga telah dimasukkan dalam Undang-Undang Negara Republik Indonesia terutama dalam Undang-Undang Republik Indonesia Nomor 23 Tahun 2014 tentang Pemerintahan Daerah yang menyebutkan yang dimaksud dengan desentralisasi fiskal adalah penyerahan sumber-sumber pembiayaan fiskal kepada daerah seiring dengan penyerahan Urusan Pemerintahan oleh Pemerintah Pusat kepada daerah 
otonom berdasarkan Asas Otonomi. Sedangkan otonomi daerah sendiri dijabarkan sebagai hak, wewenang, dan kewajiban daerah otonom untuk mengatur dan mengurus sendiri Urusan Pemerintahan dan kepentingan masyarakat setempat dalam sistem Negara Kesatuan Republik Indonesia (NKRI). Dengan melihat Undang - Undang tersebut, dapat dipahami bagaimana pentingnya peran pemerintah daerah dalam proses pembangunan daerah mereka yang telah dipercayakan pemerintah pusat dalam mengatur kebutuhan dengan menggunakan potensi yang tersedia.

Peta kemampuan keuangan daerah merupakan suatu gambaran terkait dengan kemampuan keuangan daerah. Dengan menggunakan analisis metode indeks, maka dapat diketahui peta kemampuan keuangan daerah, dimana metode indeks diukur dengan melihat kinerja PAD, yaitu share PAD terhadap belanja, growth PAD dan elasticity PAD terhadap belanja daerah.

Desentralisasi fiskal dalam kaitannya dengan otonomi daerah, ditujukan kepada kemandirian daerah, sehingga pemerintah daerah dapat menggali serta mengoptimalkan potensi daerah terutama sumber - sumber daerah.

Share PAD merupakan rasio PAD terhadap belanja rutin dan belanja pembangunan daerah. Rasio ini digunakan untuk mengukur seberapa jauh kemampuan daerah dalam membiayai kegiatan rutin serta kegiatan pembangunan. Growth merupakan angka pertumbuhan dari PAD tahun tertentu dibandingkan tahun sebelumnya. Adapun elasticity adalah rasio pertumbuhan PAD dengan pertumbuhan PDRB, rasio ini digunakan untuk mengetahui sensitivitas atau elastisitas PAD terhadap belanja daerah.

Tabel 3. Rata - Rata Share PAD, Growth PAD dan Elasticity PAD Pada Daerah Tertinggal di Provinsi Sulawesi Tengah (2015 - 2019)

\begin{tabular}{clccc}
\hline No. & \multicolumn{1}{c}{ Daerah } & Share PAD & Growth PAD & Elasticity PAD \\
& & $(\%)$ & $(\%)$ & $(\%)$ \\
\hline 1. & Banggai Kepulauan & 3,41 & 24,03 & 21,29 \\
\hline 2. & Buol & 6,76 & 17,07 & 20,85 \\
\hline 3. & Tolitoli & 7,76 & 17,26 & 17,24 \\
\hline 4. & Donggala & 6,55 & 16,93 & 8,06 \\
\hline 5. & Parigi Moutong & 8,28 & 12,52 & 11,82 \\
\hline 6. & Tojo Una-Una & 5,66 & 8,77 & 9,43 \\
\hline 7. & Sigi & 4,02 & 22,07 & 16,44 \\
\hline 8. & Banggai Laut & 3,57 & 32,85 & 22,28 \\
\hline 9. & Morowali Utara & 5,28 & 5,41 & 6,59 \\
\hline
\end{tabular}

Sumber: Hasil Pengolahan Data (2020)

Tabel 3 menjelaskan rata - rata dari tahun 2015 hingga tahun 2019 untuk share PAD, growth PAD dan elasticity PAD. Share PAD terhadap total belanja daerah paling tinggi diperoleh Kabupaten Parigi Moutong sebesar 8,28\%, hal ini berarti peran PAD antara tahun 
2015 ke tahun 2019 untuk Kabupaten Parigi Moutong sudah baik dalam membiayai belanja daerah.

Sementara Kabupaten Banggai Kepulauan, nilai rata - rata share PAD paling rendah sebesar 3,41\%, yang berarti peran PAD dalam membiayai belanja daerah antara tahun 2015 hingga tahun 2019 kurang baik.

Nilai Growth PAD yang merupakan perbandingan Pendapatan Asli Daerah (PAD) tahun ini terhadap PAD tahun sebelumnya, Kabupaten Banggai Laut mempunyai nilai tinggi rata rata growth PAD sebesar $32,85 \%$. Hal ini berarti perkembangan PAD di Kabupaten Banggai Laut antara tahun 2015 hingga tahun 2019 mengalami peningkatan.

Untuk nilai rata - rata Growth PAD yang paling rendah diperoleh Kabupaten Morowali Utara sebesar $5,41 \%$. Angka tersebut menandakan perkembangan pendapatan asli daerah selama 5 tahun antara tahun 2015 hingga tahun 2019 belum mengalami kenaikan yang signifikan.

Rata - rata elasticity PAD yang merupakan perbandingan pertumbuhan PAD terhadap pertumbuhan Produk Domestik Regional Bruto (PDRB), nilai tertinggi diperoleh Kabupaten Banggai Laut sebesar 22,28\%. Sementara, nilai rendah diperoleh Kabupaten Morowali Utara sebesar $6,59 \%$.

Setelah diketahui hasil dari masing - masing nilai indeks, maka dapat dilakukan analisis Indeks Kemampuan Keuangan.

Tabel 4. Indeks Share PAD, Growth PAD dan Elasticity PAD Pada Daerah Tertinggal di Provinsi Sulawesi Tengah (2015 - 2019)

\begin{tabular}{llccccc}
\hline \multirow{2}{*}{ No. } & \multirow{2}{*}{ Daerah } & \multicolumn{3}{c}{ INDEKS } & \multirow{2}{*}{ IKK } & $\begin{array}{c}\text { Status Kemampuan } \\
\text { Keuangan Daerah }\end{array}$ \\
\cline { 3 - 5 } & & Share & Growth & Elastisitas & & Sedang \\
\hline 1. & Banggai Kepulauan & 0,35 & 0,42 & 0,40 & 0,39 & Tinggi \\
\hline 2. & Buol & 0,46 & 0,47 & 0,40 & 0,44 & Tinggi \\
\hline 3. & Tolitoli & 0,43 & 0,48 & 0,43 & 0,45 & Tinggi \\
\hline 4. & Donggala & 0,29 & 0,59 & 0,64 & 0,51 & Tinggi \\
\hline 5. & Parigi Moutong & 0,43 & 0,44 & 0,45 & 0,44 & Tinggi \\
\hline 6. & Tojo Una-Una & 0,40 & 0,52 & 0,43 & 0,45 & Rendah \\
\hline 7. & Sigi & 0,31 & 0,33 & 0,34 & 0,33 & Tinggi \\
\hline 8. & Banggai Laut & 0,39 & 0,52 & 0,57 & 0,49 & Sedang \\
\hline 9. & Morowali Utara & 0,47 & 0,32 & 0,26 & 0,35 & \\
\hline
\end{tabular}

Sumber: Hasil Pengolahan Data (2020)

Tabel 4 menjelaskan klasifikasi dari indeks kemampuan keuangan pada daerah tertinggal di Provinsi Sulawesi Tengah yang dihasilkan dari nilai indeks share PAD, growth PAD, dan elasticity PAD pada daerah tertinggal. 
Dari tabel tersebut, nilai indeks kemampuan keuangan (IKK) pada daerah tertinggal di Provinsi Sulawesi Tengah paling tinggi dicapai Kabupaten Tojo Una - Una sebesar 0,51. Sementara nilai rendah dicapai oleh Kabupaten Sigi sebesar 0,33.

Dari data tersebut dapat dipahami bahwa Kabupaten Tojo Una - Una serta Kabupaten yang masuk dalam klasifikasi indeks kemampuan keuangan daerah tinggi, mampu dalam mengoptimalkan potensi pendapatan daerah yang dimilikinya serta menggunakannya untuk kebutuhan pembangunan di daerah masing - masing.

Sedangkan untuk Kabupaten dengan klasifikasi sedang, yaitu Banggai Kepulauan dan Morowali Utara, hanya sebatas mampu menggali potensi daerah yang dimiliki, hanya saja masih belum dapat menggunakan potensi tersebut secara optimal.

Untuk Kabupaten Banggai Laut, daerah ini belum dapat mengoptimalkan potensi kekayaan yang dimiliki, sehingga perlu untuk dilakukan intensifikasi serta ekstensifikasi pendapatan daerah.

Tabel 5. Pola Hubungan Kemampuan Keuangan Daerah Pada Daerah Tertinggal di Provinsi Sulawesi Tengah (2015 - 2019)

\begin{tabular}{cllcl}
\hline No. & Daerah & IKK(\%) & Kemampuan Keuangan & Pola Hubungan \\
& & & & \\
\hline 1. & Banggai Kepulauan & $38,6 \%$ & Sedang & Konsultatif \\
\hline 2. & Buol & $44,2 \%$ & Tinggi & Konsultatif \\
\hline 3. & Tolitoli & $44,9 \%$ & Tinggi & Konsultatif \\
\hline 4. & Donggala & $50,8 \%$ & Tinggi & Konsultatif \\
\hline 5. & Parigi Moutong & $43,8 \%$ & Tinggi & Konsultatif \\
\hline 6. & Tojo Una-Una & $45,0 \%$ & Tinggi & Konsultatif \\
\hline 7. & Sigi & $32,6 \%$ & Rendah & Konsultatif \\
\hline 8. & Banggai Laut & $49,1 \%$ & Tinggi & Konsultatif \\
\hline 9. & Morowali Utara & $34,8 \%$ & Sedang &
\end{tabular}

Tabel 5 menjelaskan pola hubungan kemampuan keuangan daerah tertinggal di Provinsi Sulawesi Tengah, dimana seluruh Kabupaten daerah tertinggal di Provinsi Sulawesi Tengah pola hubungan adalah konsultatif. Pola ini berarti campur tangan pemerintah pusat sudah mulai berkurang dimana peran pemerintah pusat hanya memberikan konsultasi (pengarahan), sehingga daerah dianggap sudah mampu dalam melaksanakan otonomi daerah.

\section{Kesimpulan}

Berdasarkan atas hasil yang diperoleh, maka dapat ditarik kesimpulan bahwa pola kemampuan keuangan daerah menunjukkan pada daerah tertinggal di Provinsi Sulawesi Tengah, status kapasitas kemampuan keuangan daerah tinggi didapat oleh Kabupaten Buol, 
Toli - Toli, Donggala, Parigi Moutong, Tojo Una - Una dan banggai laut. Sementara pola kemampuan keuangan daerah yang menunjukkan klasifikasi sedang yaitu Kabupaten Banggai Kepulauan dan Morowali Utara, sedangkan pola kemampuan keuangan daerah yang menunjukkan klasifikasi rendah yaitu Kabupaten Sigi.

Dari kesimpulan tersebut, ada beberapa hal yang dapat menjadi perbaikan dalam mengatasi pola hubungan kemampuan keuangan daerah, diantaranya 1) Daerah yang pola hubungan keuangan daerah berada pada klasifikasi sedang, perlu mendapat dorongan agar pendapatan asli daerah bertumbuh, akan tetapi juga perlu disertai belanja daerah yang rasional sesuai dengan kapasitas keuangan daerah riil-nya. 2) Bagi daerah yang klasifikasi kemampuan keuangan daerah rendah, perlu ada upaya dalam hal peningkatan pendapatan asli daerah. Upaya yang dapat dilakukan yaitu mengoptimalkan potensi daerah yang dimiliki oleh masing masing Kabupaten/Kota. 3) Belanja daerah pada kenyataannya dapat meningkatkan pertumbuhan ekonomi suatu wilayah, hanya saja jika digunakan secara berlebihan bisa menyebabkan defisit anggaran. Untuk mengurangi hal tersebut, maka pemerintah daerah perlu melakukan keseimbangan antara pendapatan daerah terhadap belanja daerahnya. 4) Daerah tertinggal di Provinsi Sulawesi Tengah perlu lebih lagi dalam melakukan optimalisasi serta mampu menggali seluruh potensi yang ada di daerahnya berdasarkan atas asset maupun kekayaan daerah, yang pada akhirnya dapat meningkatkan kemampuan keuangan daerahnya. Cara yang paling dapat dilakukan yaitu melalui intensifikasi dan ekstensifikasi pendapatan daerah.

\section{Daftar Pustaka}

Haryanto, J. T. (2016). Desentralisasi Fiskal Seutuhnya. Technology. https://doi.org/10.1007/s11187-017-9901-7

Haryanto, J. T. (2017). Analisis Perbandingan Peta Kemampuan Keuangan Daerah Penghasil Sda Dan Non-Sda Di Era Desentralisasi Fiskal Studi Kasus: Penggunaan Metode Kuadran. Jurnal Ekonomi Dan Kebijakan Publik, 8(2), 103-116. https://doi.org/10.22212/jekp.v8i2.821

Haryanto, J. T. (2018). Analisis Kemandirian Keuangan Daerah (Studi Kasus: Provinsi Banten Tahu 2011-2015). Inovasi. https://doi.org/10.33626/inovasi.v15i1.22

Kamaroellah, R. A. (2017). Analisis Tingkat Kemampuan Keuangan Daerah Dalam Mendukung Pelaksanaan Otonomi Daerah. NUANSA: Jurnal Penelitian IImu Sosial Dan Keagamaan Islam, 14(1), 123. https://doi.org/10.19105/nuansa.v14i1.1316

Rinaldi, U. (2013). Kemandirian Keuangan Dalam Pelaksanaan Otonomi Daerah. Jurnal EKSOS, 8(22), 105-113. https://core.ac.uk/download/pdf/11718149.pdf

Sasana, H. (2016). Dampak Implementasi Desentralisasi Fiskal Terhadap Pertumbuhan Ekonomi Dan Stabilitas Harga Di Provinsi Di Indonesia. Media Ekonomi Dan Manajemen, 30(1), 59-67.

Savitry, E., Saleh, H. A., \& Arifin, I. (2011). Analisis Kemampuan Keuangan Daerah dalam 
Pelaksanaan Otonomi Daerah Tahun 2007-2011 di Kota Makassar. Government: Jurnal IImu Pemerintahan, 4(1), 23-34.

Susanto, H. (2014). Analisis Kemampuan Keuangan Daerah Pemerintah Propinsi Nusa Tenggara Barat. Jurnal Organisasi Dan Manajemen, 10(1), 15-26. 